\title{
13. The geological significance of electrical conductivity anomalies of the Ordovician- Silurian Moffat Shale Group, Northern Ireland
}

\author{
Mark Cooper, ${ }^{\mathrm{I}}$ James Floyd, ${ }^{\mathrm{I}}$ Gareth Barker, ${ }^{\mathrm{I}}$ \\ Mohammednur Desissa Ture, ${ }^{2}$ James Hodgson ${ }^{2}$, Brian \\ McConnelL ${ }^{2}$ and Matthew Warke ${ }^{3}$
}

How to cite this chapter:

Cooper, M.R., Floyd, J.D., Barker, G.J., Ture, M.D., Hodgson, J.A., McConnell, B.J. and Warke, M.R., 2016

'The geological significance

of electrical conductivity anomalies of the OrdovicianSilurian Moffat Shale Group, Northern Ireland' in M.E.

Young (ed.), Unearthed: impacts of the Tellus surveys of the north of Ireland. Dublin. Royal Irish Academy.

DOI:10.3318/ 978-1-908996-88-6.ch13
The Tellus airborne geophysical survey revealed sets of narrow, linear, north-east to southwest, mostly parallel electrical conductivity (electromagnetic - EM) anomalies in the Longford-Down area. Subsequent geological mapping and ground geophysics have demonstrated that the anomalies coincide with and match the width of bedrock outcrop of the Moffat Shale Group. Ground-based geophysical surveys show variations in conductivity with highest values corresponding to carbon-rich mudstones. These findings allow the regional airborne geophysics to be interpreted with greater confidence for incorporation into bedrock geological maps, which underpin aspects of economic and environmental decision making.

\section{Geological mapping of the Longford-Down Terrane}

Geological maps underpin decision making in a diverse range of public and corporate applications. They are essential in the search for natural mineral resources; for planning new infrastructure, waste disposal and transportation; for environmental management and monitoring; and for the assessment of hazards such as flooding, landslides and ground subsidence. Geological mapping is therefore a core function of the Geological Surveys that underpins modern economic development and land-use management. This chapter illustrates how high-resolution airborne geophysics can improve geological maps, particularly in areas where bedrock is concealed by superficial deposits.

Geological Survey of Northern Ireland, Belfast.

${ }^{2}$ Geological Survey of Ireland, Dublin.

${ }^{3}$ University of Manchester. 


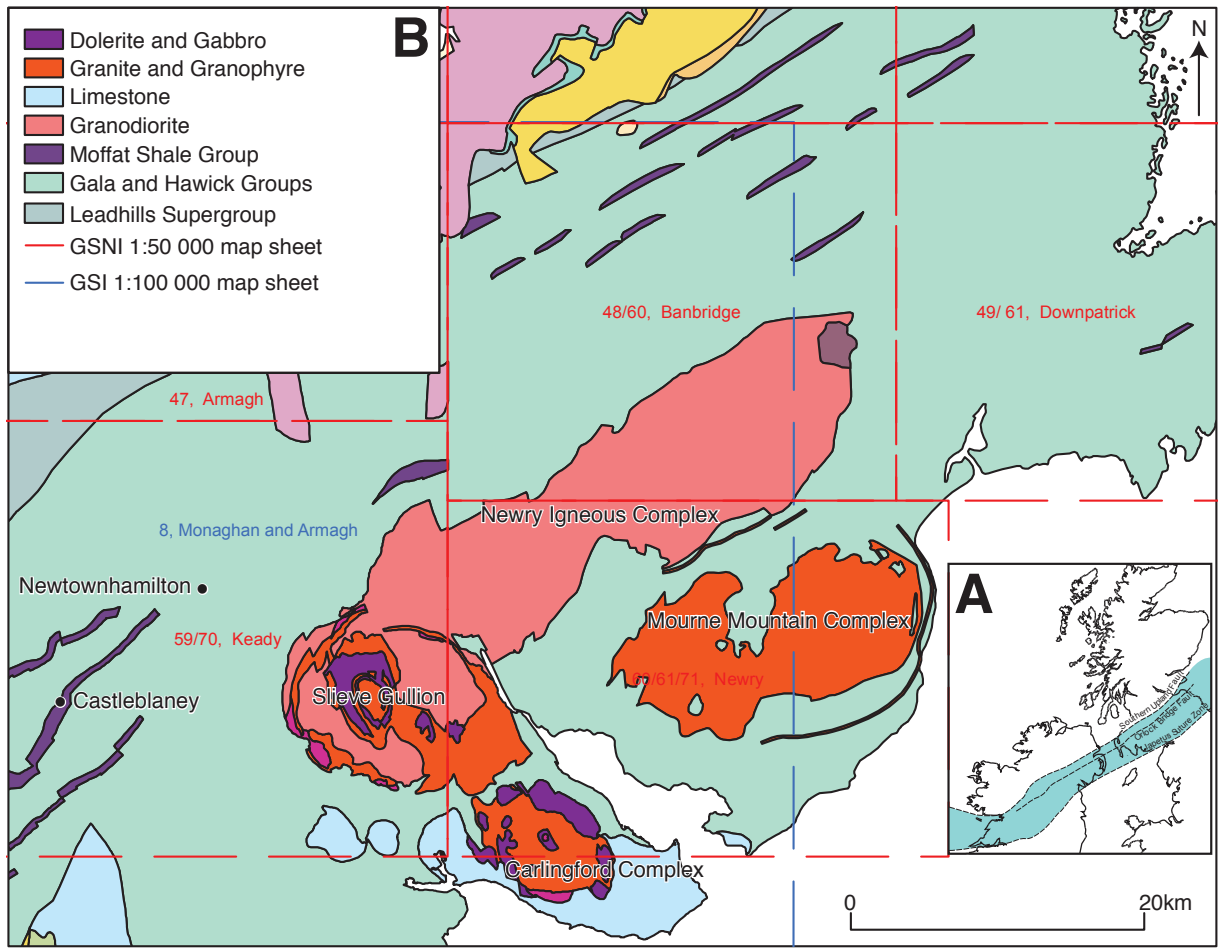

The Longford-Down area, some $6000 \mathrm{~km}^{2}$, stretches across counties Down and Armagh in Northern Ireland, and counties Louth, Monaghan, Cavan and Longford in the Republic. It is part of the Southern Uplands - Down-Longford terrane that extends into Scotland (Fig. 13.1). Crushed rock aggregate is widely quarried and the area is in places mineralised with base metals and potentially economic gold deposits. There is also some potential for exploiting deep geothermal energy in granitic intrusions of late Silurian to Devonian and Palaeogene age.

Bedrock of the Longford-Down terrane comprises packages of rock known as 'tracts', which are largely composed of turbiditic greywacke sandstones, siltstones and mudstones. These rocks are divided into the Ordovician Leadhills Supergroup, the Silurian Gala and Hawick groups, and the mudstone-dominated Moffat Shale Group (MSG), which commonly crops out to the north of the north-easterly striking faults that bound the tracts (Anderson, 2004).

This chapter complements a previous regional scale interpretation of Tellus airborne EM anomalies by Beamish et al. (2010) by presenting the first results of ground investigation of selected airborne anomalies. This work includes detailed geological mapping to compare anomaly width with actual bedrock outcrop of MSG, and ground-based geophysics to examine internal variations in the MSG that might more specifically explain the EM
Figure 13.1. Simplified Longford-Down bedrock geology (after GSI, 2006). Moffat Shale Group occurs as thin slivers associated with north-east to south-west tract boundary faults. GSNI and GSI map sheets are shown for reference. 

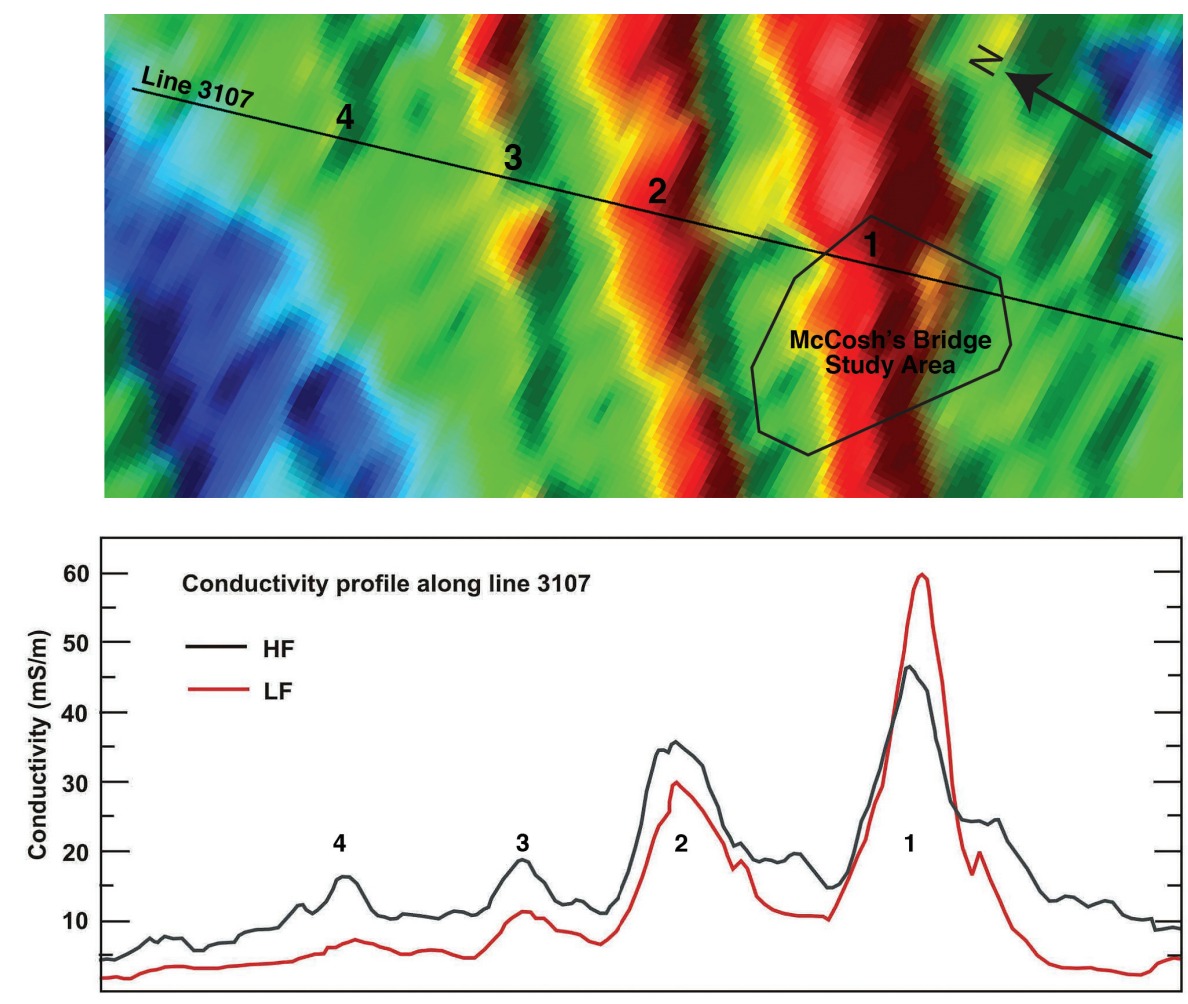

Figure 13.2. McCosh's Bridge site. Above: Tellus electrical conductivity image showing

three prominent parallel anomalies that narrow and weaken from south-east to north-west. Below: airborne conductivity profile 3107 , showing the three clear conductivity anomalies and a weaker fourth, in both the low and high frequency. anomalies. This study adds confidence to interpretation of Tellus EM data for incorporation into geological maps that are being updated by the two Geological Surveys.

\section{Case study area}

The case study area selected for investigation, referred to as McCosh's Bridge, lies immediately south-west of Newtownhamilton in County Armagh (Fig. 13.1), close to the border with County Monaghan. This location was chosen because of the clarity of the EM anomalies (Fig. 13.2), the presence of available bedrock exposure, and the absence of major sources of anthropogenic interference.

\section{Ground InVESTIGATION METHODS}

\section{Geological mapping}

Detailed, 1:5000 scale, field mapping of bedrock and superficial deposits was made across the case study area. Identifications of dominant lithologies and measurement of key structural data, such as strike and dip of bedding (including way-up), faults and thrusts were made for bedrock. The distribution and nature of superficial deposits was also mapped (Fig. 13.3). 


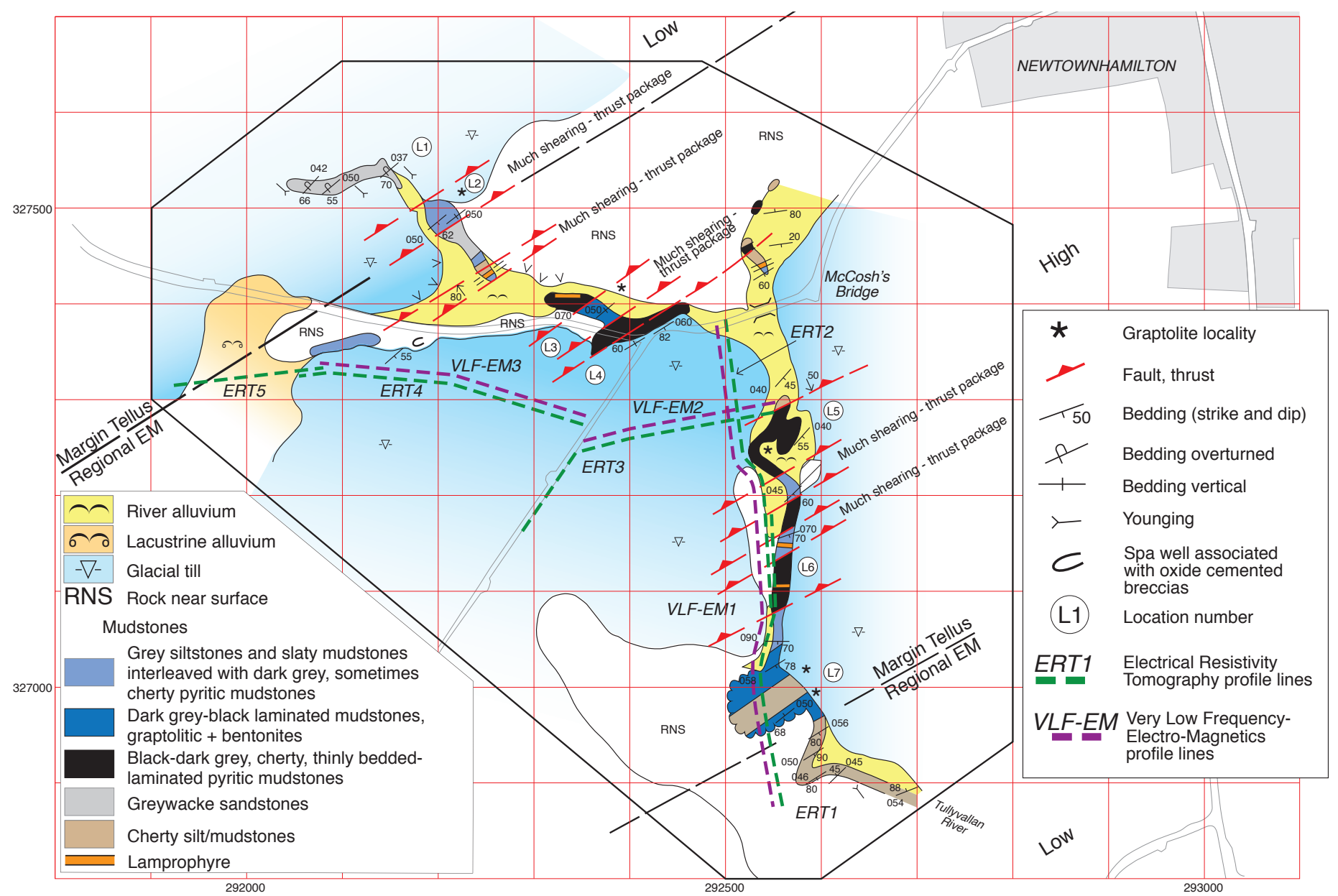

\section{Ground-based geophysics}

Five electrical resistivity tomography (ERT) profiles were surveyed across the bedding of the case study area. Three very low frequency electromagnetic (VLF-EM) profiles were acquired parallel to the ERT lines.

\section{$V L F-E M$}

This standard electromagnetic survey maps shallow variations of electrical conductivity. The primary signal source for VLF-EM prospecting systems is radio stations that radiate EM waves in the VLF bands $(15-30 \mathrm{kHz})$. At distances far from the transmitters the primary fields resemble plane EM waves with horizontal magnetic and vertical electric fields. The primary electric field generates eddy currents which produce much smaller secondary magnetic fields in buried electrical conductors. The secondary magnetic field comprises a component in-phase (IP) with the primary field and a quadrature (Q) component at $90^{\circ}$, or out-of-phase.

Responses from transmissions from three different stations at three VLF frequencies $(19.6,20.9$ and $23.4 \mathrm{kHz})$ were recorded along each of the three profiles, using a Scintrex ENVI system. In-phase, quadrature, total field, tilt, resistivity and phase components were measured from the three VLF stations. The IP component of $19.6 \mathrm{kHz}$ (Anthorn, Cumbria, transmitter) is presented here since it gave the strongest signal and propagates
Figure 13.3. McCosh's Bridge site: bedrock and superficial geology; the margins of Tellus EM anomaly 1; locations of VLF-EM and ERT traverses. 
more deeply than the two higher frequencies. The VLF data were filtered according to the method of Karous and Hjelt (1983), using KHFFILT software of Pirttijärvi (2004), which also generated vertical pseudo-sections showing the density of the induced eddy currents.

\section{ERT}

This standard electrical survey technique generates a vertical cross-section of the variation of electrical resistivity beneath a linear array of electrodes laid on the ground. A Tigre resistivity system using a Wenner array setup was employed, with $5 \mathrm{~m}$ electrode separation. A small current $(<50 \mathrm{~mA})$ is passed between different electrodes and a resistance measured. A $2 \mathrm{D}$ section of the apparent resistivity of the subsurface was then produced using the inversion software Res2Dinv (Loke and Barker, 1996). The depth of penetration increases with the number of electrodes and length of profile. Depth penetrations of up to $50 \mathrm{~m}$ below ground level were achieved along the longest $(315 \mathrm{~m})$ profile.

\section{RESUlTS OF THE GROUND SURVEYS}

\section{Bedrock geology}

Geological mapping (Fig. 13.3) revealed bedrock exposure in streams and areas of rock near surface associated with Tellus EM anomaly 1 (Fig. 13.2). Bedrock exposure diminished to the north-west due to the presence of thick glacial till, so the case study area was restricted to this anomaly. Stream section mapping in the area of anomaly 2 did however show the presence of dark grey, slaty mudstone at outcrop. At the north-west corner of the area mapped, medium-very thick bedded (1-10 m thick) greywacke sandstone is inverted, dips steeply to the southeast and youngs to the northwest (Location 1, Figs 13.3 and 13.4a). Some $150 \mathrm{~m}$ downstream (Location 2, Fig. 13.3), the first significant mudstones encountered are composed of dark grey-cream, slaty mudstones and siltstones interleaved with dark grey, sometimes cherty, pyritic mudstones, all of which show much evidence of shearing and colour change or bleaching. These and other similar intervals downstream are interpreted as thrust packages. Further downstream (Locations 3, Fig. 13.3), dark grey to black laminated mudstones were found containing graptolites and bentonites. A third mudstone type is present at various places in the stream section (e.g. Locations 4 and 5, Fig. 13.3), and is composed of black-dark grey, cherty, thinly bedded-laminated, pyritic mudstone. The strike of bedding within mudstone was predominantly north-east to southwest, and dips varied from vertical to moderate to the north-west and south-east. Way-up within the mudstones was not identifiable in the field. South-west of Location 7 (Fig. 13.3) greywacke sandstone returns as the dominant lithology.

In addition to the numerous sheared thrust packages (as described above for Location 2), other strike parallel tectonic structures were observed. These include a spectacular dislocation surface (Location 4, Fig. 13.4b) that dips $15^{\circ}$ to the north-west and displays much brecciation, gouge development, bleaching and mineralisation (quartz and pyrite) 

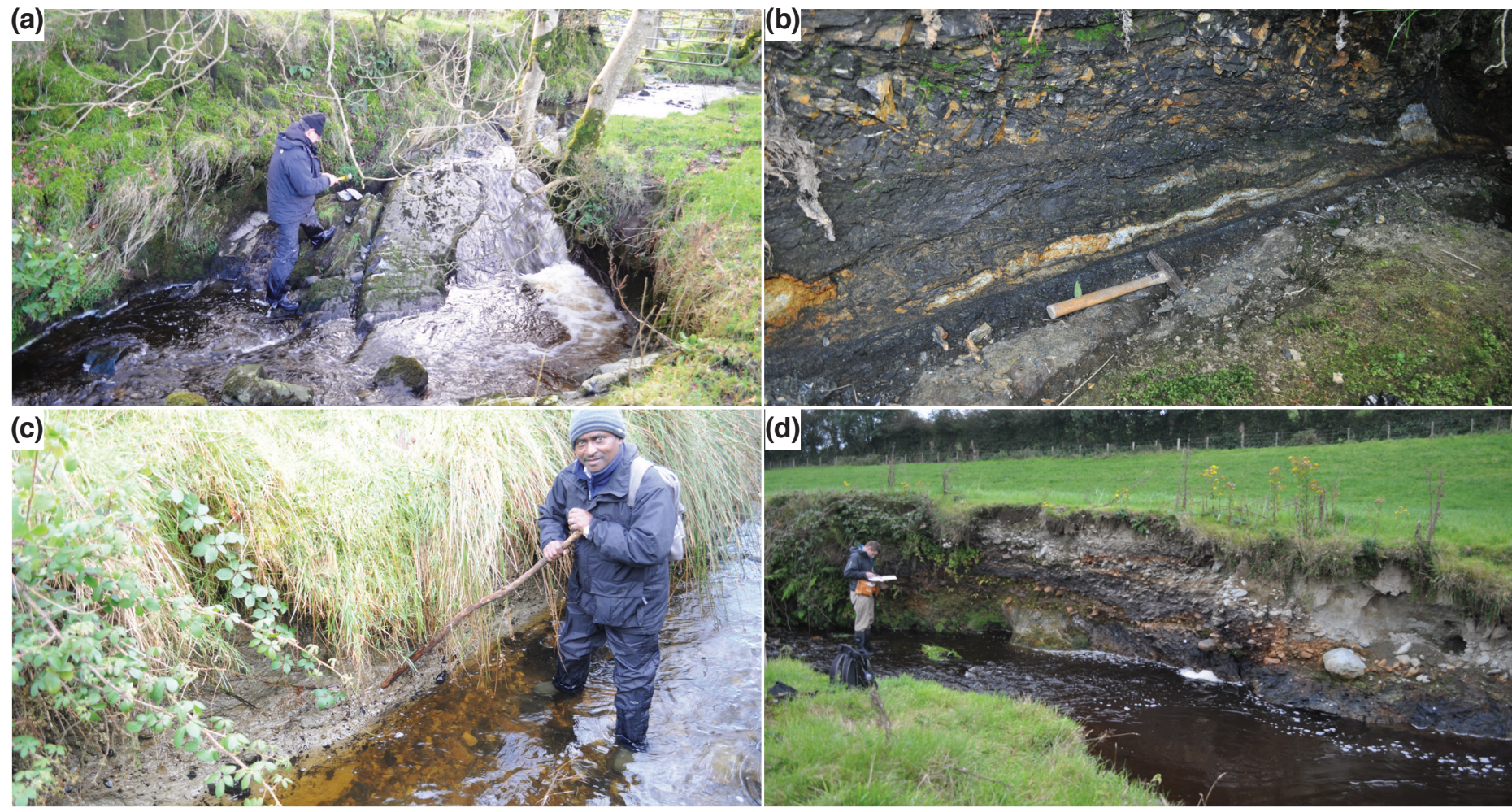

related to fluid flow. Several highly altered, mica-rich, lamprophyre dykes were also identified cross-cutting the mudstones and striking west to east. These minor intrusions most likely belong to the Late Caledonian population present in the area and associated with the Newry Igneous Complex (Reynolds, 1931; Cooper and Johnston, 2004; Cooper et al., 2013).

\section{Superficial deposits}

Glacial till is present across much of the area in the form of north-northwest to southsoutheast aligned drumlins (Greenwood and Clark, 2008). As a consequence, till tends to thicken rapidly away from the modern streams and rivers (Fig. 13.3). The composition of tills across Northern Ireland tends to reflect underlying bedrock (Dempster et al., 2013) and the till here is no exception; it is a sandy, clayey silt with locally derived clasts of greywacke, siltstone and mudstone to boulder grade (Fig. 13.4c). An area of lacustrine alluvium is present at the western margin of the mapped area and is composed of clayey silt with thin lenses of sand and gravel. Adjacent to the streams and Tullyvallan River, alluvium continues to form and is composed of clasts derived from bedrock and till that range from boulder to silt grade (Fig. 13.4d).
Figure 13.4. McCosh's Bridge site: (a) thick, inverted greywacke sandstone bed; (b) thrust surface with fault gouge, breccias and bleaching related to fluid flow; (c) glacial till; (d) river alluvium deposits. 
a

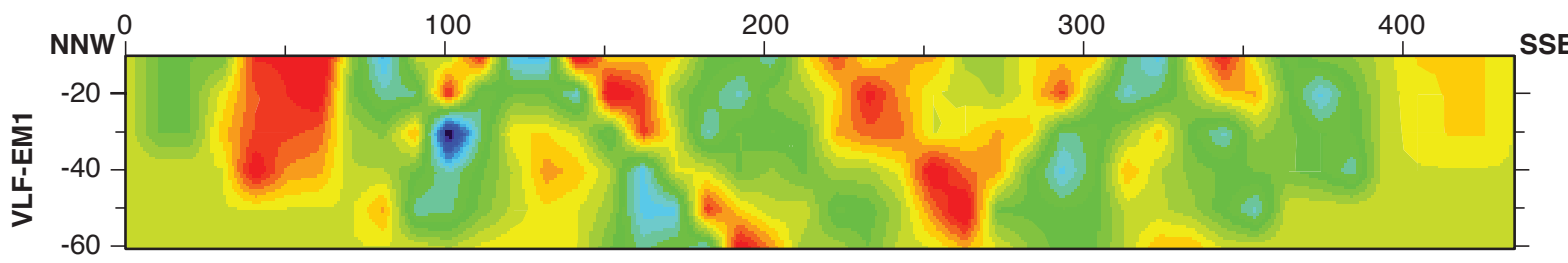
SSE

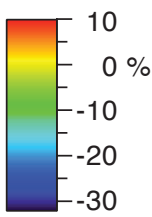

b
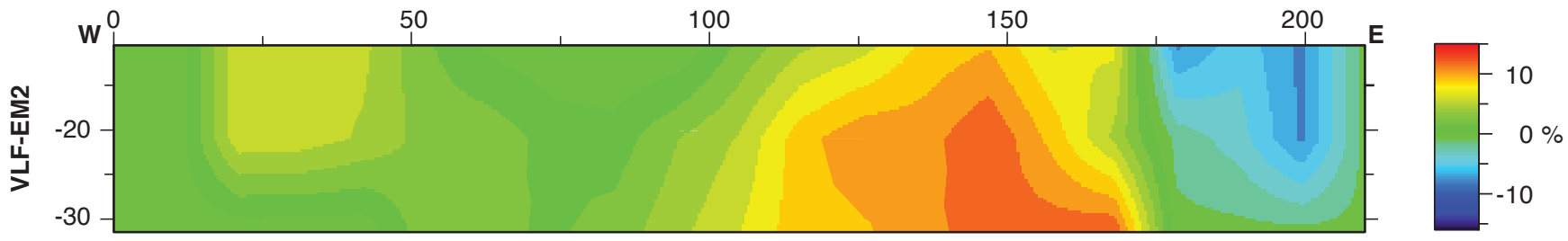

c

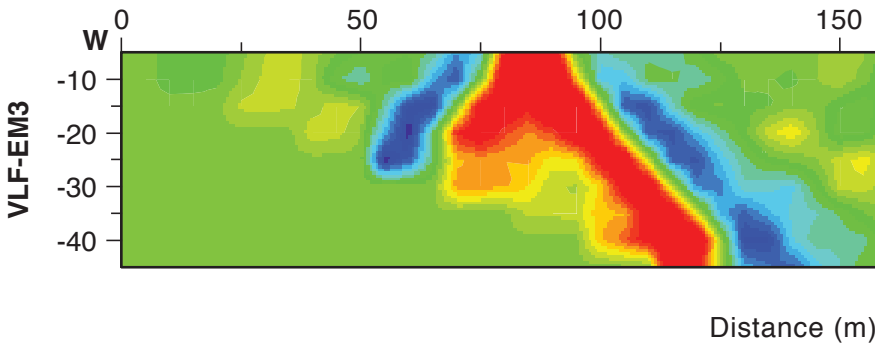

Figure 13.5. VLF-EM profiles. The coloured scale shows the intensity of the in-phase (IP) component of the current density as $\%$ of the primary field. Horizontal and vertical scales in metres.

\section{Geophysical surveys}

The locations of the traverses are shown in Fig. 13.3 and the VLF and ERT sections in Figs 13.5 and 13.6 respectively.

- Fig. 13.5a. Line VLF-EM1, $435 \mathrm{~m}$, lies parallel to the airborne survey line and nearly perpendicular to the strike of the conductors. Two well-defined conductors (orange and red) dipping to the south-east occur at $c .150$ and $220 \mathrm{~m}$. A third anomaly at $c .50 \mathrm{~m}$ is a response from a power line. The VLF anomalies at $c .150$ and $220 \mathrm{~m}$ correlate with black-dark grey, cherty, pyritic mudstone (Fig. 13.3). Field observation shows that the black mudstones contain graphite, which is conductive and easily mapped by VLF. In contrast, more resistive responses (blue and green) correlate with the grey slaty mudstones and the dark grey-black, laminated mudstones.

- Fig. 13.5b. Line VLF-EM2, 210 m, crosses elevated ground over thick glacial till. The response over this line is not as clear as line (a).

- Fig. 13.5c. Line VLF-EM3, $290 \mathrm{~m}$. The anomaly observed at $80 \mathrm{~m}$ is again associated with black-dark grey, cherty, pyritic mudstone.

On the ERT profiles (Fig. 13.6) areas of lower conductivity (green and blue) correlate closely with mapped greywacke sandstones, e.g. the end of ERT1 and most of ERT5, while zones of high conductivity (orange-red-purple) coincide with the range of mudstones 

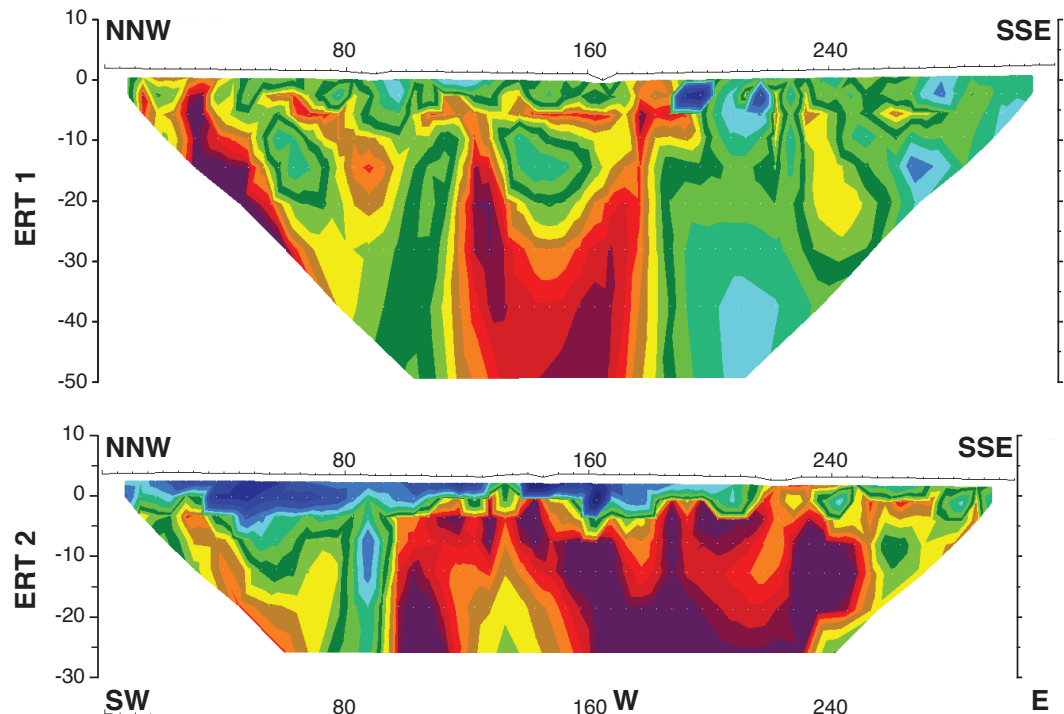

c
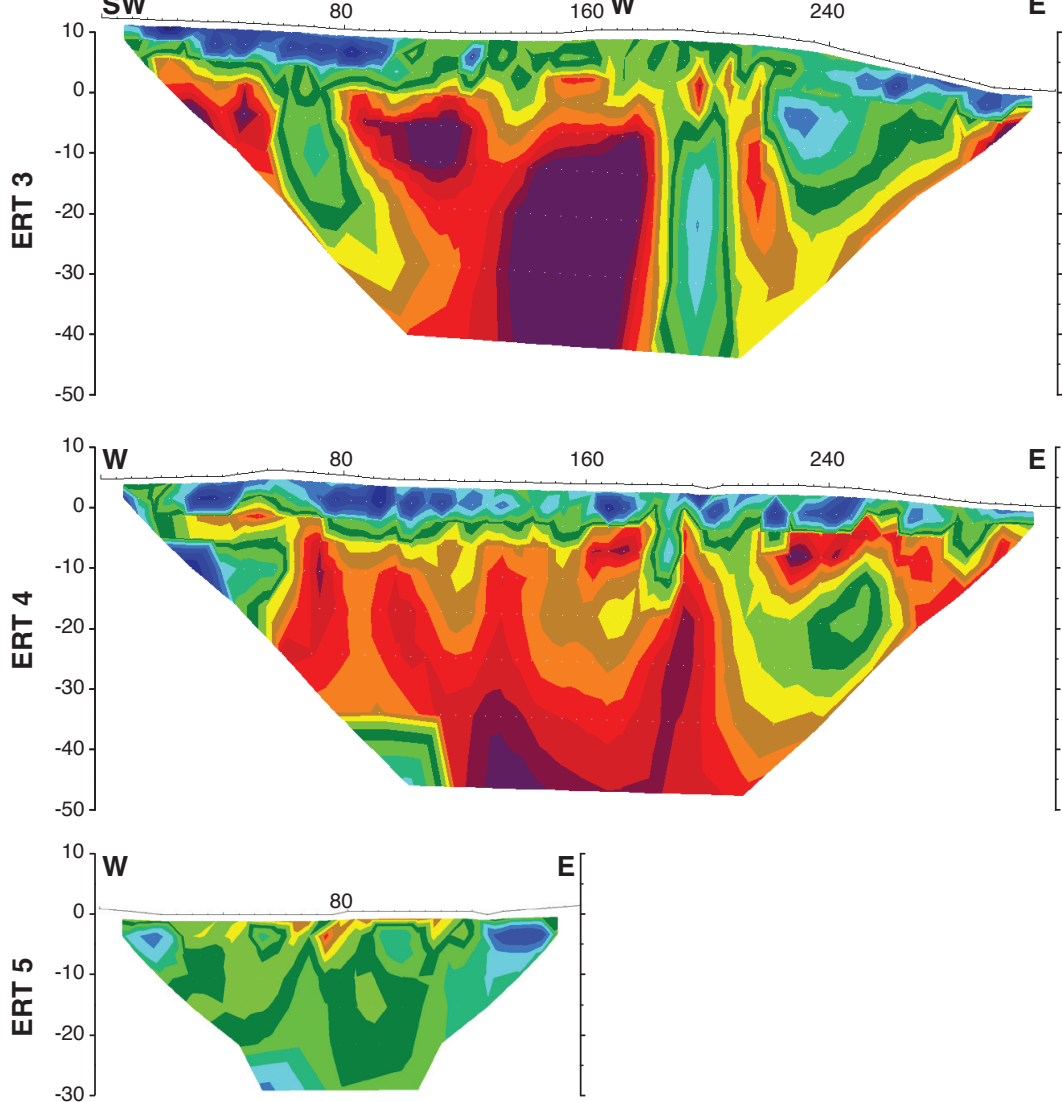

Figure 13.6. ERT profiles. The coloured scale shows resistivity in $\Omega \mathrm{m}$. Horizontal and vertical scales in metres. 
identified during mapping. Unlike the VLF-EM, this method does not appear to differentiate between the mudstone types but comparison of the ERT profiles with the regional Tellus EM anomaly (Fig. 13.3) reveals a close match of anomaly width, which is important in geological mapping.

\section{Conclusions}

This brief study reveals a close match between regional airborne EM anomalies and mapped geology, which is important in that it allows the width and lateral extent of MSG packages to be mapped using the regional geophysical data set. This knowledge is being incorporated into active mapping campaigns north and south of the border (Fig. 13.1).

Ground-based geophysics has detected variations in the conductivity of the MSG packages, with the black-dark grey, cherty, pyritic mudstone type being most conductive and the grey-cream, slaty mudstones being least conductive. Field work shows that the latter mudstone type has been affected by much thrusting and shearing, which appears to have reduced its conductivity. In addition to shearing, there is much colour change of these mudstones (from black-dark grey to light grey-cream), which is interpreted to have taken place through fluid flow during regional deformation. Fluid flow appears to have removed carbon, possibly in the form of graphite, from the mudstones along anastomosing, shear-related discontinuities, which could greatly reduce the overall conductivity of the rock; petrology and scanning electron microscopy analysis would be required to confirm whether or not this is the case. Further investigation is also required to investigate the possible effects of overburden, primarily glacial till, on the characteristics of the Tellus EM anomalies.

The results presented here add confidence to the interpretation of Beamish et al. (2010), which revealed regional scale geological structures in the Longford-Down area, including the presence of a major strike-slip duplex in the ${ }^{\circ}$ area (mapped in detail on Beamish et al., 2010, Fig. 4) and significant strike swing in the area west of Slieve Gullion, County Armagh (mapped on Beamish et al., 2010, Figs 5 and 6). These bedrock features are important in that they are associated with igneous intrusions, some of which have potential for geothermal energy and mineral deposits. Interpretation of Tellus and Tellus Border EM data is now being applied to revising and refining the geological maps on both sides of the border. This is especially important in areas where bedrock is concealed by thick glacial deposits. The new maps will provide a regional bedrock context for potentially significant gold deposits and will allow better constraints on the extent of certain greywacke sandstone tracts that have premium value as high polished road stone.

\section{ACKNOWLEDGEMENTS}

MRC and JDF publish with the permission of the Executive Director of the British Geological Survey (NERC). MDT, BJM and JAH publish with the permission of the Director of the Geological Survey of Ireland. 


\section{REFERENCES}

Anderson, T.B., 2004 'Southern Uplands - Down-Longford Terrane', in W.I. Mitchell (ed.), The Geology of Northern Ireland: Our Natural Foundation. Second edition, 41-60. Belfast. Geological Survey of Northern Ireland.

Beamish, D., Kimbell, G.S., Stone, P. and Anderson, T.B., 2010 'Regional conductivity data used to reassess Early Palaeozoic structure in the Northern Ireland sector of the Southern Uplands - Down-Longford terrane', Journal of the Geological Society, 167, 649-57. Available at http://nora.nerc.ac.uk/10070/. http://dx.doi.org/10.1144/0016-76492009-122.

Cooper, M.R., Crowley, Q.G., Hollis, S.P., Noble, S.R. and Henney, P.J., 2013 'A U-Pb age for the Late Caledonian Sperrin Mountains minor intrusions suite in the north of Ireland: timing of slab-break off in the Grampian terrane and the significance of long-lived deep crustal lineaments', Journal of the Geological Society, 170, 603-14. Available at http://nora.nerc.ac.uk/503145/. http://dx.doi.org/10.1144/jgs2012-098.

Cooper, M.R. and Johnston, T.P., 2004 'Late Palaeozoic intrusives', in W.I. Mitchell (ed.), The Geology of Northern Ireland: Our Natural Foundation. Second edition, 61-8. Belfast. Geological Survey of Northern Ireland.

Dempster, M., Dunlop, P., Scheib, A. and Cooper, M.R., 2013 'Principal Component Analysis of geochemistry of soils developed on till in Northern Ireland', Journal of Maps, 9, 3, 373-89. Available at http://nora.nerc.ac.uk/503933/. http://dx.doi.org/10.1080/17445647.2013.789414.

Geological Survey of Ireland (GSI), 2006. Bedrock Geological Map of Ireland. 1:500,000. Dublin. Geological Survey of Ireland.

Greenwood, S.L. and Clark, C.D., 2008 'Subglacial bedforms of the Irish Ice Sheet', Journal of Maps, 2008, 332-57.

Karous, M. and Hjelt, S.E, 1983 'Linear filtering of VLF dip-angle measurements', Geophysical Prospecting, 31, 5, 782-94.

Loke, M.H. and Barker, R.D., 1996 'Practical techniques for 3D resistivity surveys and data inversion', Geophysical Prospecting, 44, 3, 499-523.

Pirttijärvi, M., 2004 KHFFILT: Karous-Hjelt and Fraser filtering of VLF measurements (computer program). Version 1.1a (c). Available at: https://wiki.oulu.fi/pages/ viewpage.action?pageId $=20677974$.

Reynolds, D.L., 1931 'The dykes of the Ards Peninsula', Geological Magazine, 65, 97-111 and $145-65$. 
Unearthed: impacts of the Tellus surveys of the north of Ireland

First published in 2016 by the

Royal Irish Academy

19 Dawson Street

Dublin 2

www.ria.ie

Copyright (C) 2016 Royal Irish Academy

ISBN: 978-1-908996-88-6

The articles in this book are open access and distributed under the terms of the Creative Commons Attribution 4.0 licence, which permits unrestricted use, distribution and reproduction in any medium, provided the original authors and source are credited. To view a copy of this licence, visit https://creativecommons.org/licenses/by/4.0/

Except where noted:

Geological mapping for Northern Ireland / Tellus data are provided by the Geological Survey of Northern Ireland.

Geological mapping for Ireland / Tellus Border data are provided by the Geological Survey of Ireland.

Topographic mapping for Northern Ireland is derived from Land and Propery Services Open Data and contains public sector information licensed under the Open Government Licence v3.0. (http://www.nationalarchives.gov.uk/doc/open-governmentlicence/version/3/).

Topographic mapping for Ireland is derived from Ordnance Survey of Ireland Open Data (https://creativecommons.org/licenses/by/4.0/legalcode).

While every effort has been made to contact and obtain permission from holders of copyright, if any involuntary infringement of copyright has occurred, sincere apologies are offered, and the owner of such copyright is requested to contact the publisher.

British Library Cataloguing-in-Publication Data. A catalogue record is available from the British Library.

Design: Alex Donald, Geological Survey of Northern Ireland.

Index: Brendan O'Brien.

Printed in Poland by L\&C Printing Group. 


\section{Table of Contents:}

\section{Prelim}

DOI: https://doi.org/10.7486/DRI.b851k323d

\section{Chapter 1}

The Tellus geosciences surveys of the north of Ireland: context, delivery and impacts

DOI: https://doi.org/10.7486/DRI.st74s528d

\section{Chapter 2}

The Tellus airborne geophysical surveys and results DOI: https://doi.org/10.7486/DRI.t148tx96z

\section{Chapter 3}

The Tellus geochemical surveys, results and applications

DOI: https://doi.org/10.7486/DRI.t722wq645

\section{Chapter 4}

Stakeholder engagement for regional geoscientific surveying: the Tellus Border communications campaign

DOI: https://doi.org/10.7486/DRI.w089fr763

\section{Chapter 5}

Mineral resources and Tellus: the essential balance DOI: https://doi.org/10.7486/DRI.wd37kb12s

\section{Chapter 6}

Gold exploration in the north of Ireland: new targets from the Tellus Projects

DOI: https://doi.org/10.7486/DRI.wh24m696v

\section{Chapter 7}

Using soil geochemistry to investigate gold and base metal distribution and dispersal in the glaciated north of Ireland

DOI: https://doi.org/10.7486/DRI.wm11n3806

\section{Chapter 8}

Critical metals for hightechnology applications: mineral exploration potential in the north of Ireland DOI: https://doi.org/10.7486/DRI.wp98p0649

\section{Chapter 9}

A natural laboratory for critical metals investigations in the Mourne Mountains granites

DOI: https://doi.org/10.7486/DRI.cc08ww45f

\section{Chapter 10}

Geothermal potential of granitic rocks of the Mourne Mountains

DOI: https://doi.org/10.7486/DRI.ff36jm09f

\section{Chapter 11}

Shape and intrusion history of the Late Caledonian

Newry Igneous Complex, Northern Ireland

DOI: https://doi.org/10.7486/DRI.2v248822m

\section{Chapter 12}

Using Tellus data to enhance targeting of volcanogenic massive sulphide mineralisation in the Tyrone Igneous Complex

DOI: https://doi.org/10.7486/DRI.5x226w262

\section{Chapter 13}

The geological significance of electrical conductivity anomalies of the Ordovician- Silurian Moffat Shale Group, Northern Ireland

DOI: https://doi.org/10.7486/DRI.6m31f4149

\section{Chapter 14}

Faults, intrusions and flood basalts: the Cenozoic structure of the north of Ireland

DOI: https://doi.org/10.7486/DRI.90205h306

\section{Chapter 15}

Information for agriculture from regional geochemical surveys: the example of soil $\mathrm{pH}$ in the Tellus and Tellus Border data

DOI: https://doi.org/10.7486/DRI.dv14c8060

\section{Chapter 16}

An ecohydrological investigation of wetlands in the border counties of Ireland: a framework for a holistic understanding of wetland systems DOI: https://doi.org/10.7486/DRI.hd775d90j 
Chapter 17

Assessing nutrient enrichment risk to groundwaterdependent ecosystems in the border counties of Ireland DOI: https://doi.org/10.7486/DRI.k356pk18j

\section{Chapter 18}

Mapping the terrestrial gamma radiation dose

DOI: https://doi.org/10.7486/DRI.k930rb86z

\section{Chapter 19}

Soils and their radiometric characteristics

DOI: https://doi.org/10.7486/DRI.mp495t62g

\section{Chapter 20}

Modelling in-house radon potential using Tellus data and geology to supplement inhouse radon measurements

DOI: https://doi.org/10.7486/DRI.ns06hm86z

\section{Chapter 21}

Determining geochemical threshold values from the Tellus data sets: the examples of zinc and iodine| DOI: https://doi.org/10.7486/DRI.r2087418g

\section{Chapter 22}

Identification of the geochemical signatures of diffuse pollution in the Tellus Border soil data set, using source apportionment

DOI: https://doi.org/10.7486/DRI.wh24m698d

\section{Chapter 23}

Stream sediment background concentrations in mineralised catchments in Northern Ireland: assessment of 'pressures' on water bodies in fulfilment of Water Framework Directive objectives DOI: https://doi.org/10.7486/DRI.x633tf86g

\section{Chapter 24}

Mapping metallic contamination of soils in the Lower Foyle catchment

DOI: https://doi.org/10.7486/DRI.9k42bv355

\section{Chapter 25}

Refining the human health risk assessment process in Northern Ireland through the use of oral bioaccessibility data

DOI: https://doi.org/10.7486/DRI.9p29cr199

\section{Chapter 26}

Combining environmental and medical data sets to explore potential associations between environmental factors and health: policy implications for human health risk assessments

DOI: https://doi.org/10.7486/DRI.9s16dn03n

\section{Chapter 27}

Mapping a waste disposal site using Tellus airborne geophysical data

DOI: https://doi.org/10.7486/DRI.9w03fh87q

\section{Chapter 28}

The use of aero-magnetics to enhance a numerical groundwater model of the Lagan Valley aquifer, Northern Ireland

DOI: https://doi.org/10.7486/DRI.9z90gd711

\section{Chapter 29}

Carbon sequestration in the soils of Northern Ireland: potential based on mineralogical controls DOI: https://doi.org/10.7486/DRI.b277h9556

\section{Chapter 30}

Spatial distribution of soil geochemistry in geoforensics DOI: https://doi.org/10.7486/DRI.b564j6392

\section{End matter}

DOI: https://doi.org/10.7486/DRI.bc38m007j 